\title{
HEPを応用して構築した予測モデル によるマダイの漁場環境評価
}

\author{
市瀬 友啓 1 -中桐 栄 2 島田 広昭 ${ }^{3}$ - 古林 将4 \\ 1正会員 兵庫県県土整備部土木局港湾課（ $=650-8567$ 兵庫県神戸市中央区下山手通5-10-1） \\ E-mail: tomohiro_ichise@pref.hyogo.lg.jp \\ 2農修 兵庫県農政環境部農林水産局水産課（同上） \\ E-mail: sakae_nakagiri@pref.hyogo.lg.jp \\ 3正会員 博(工) 関西大学環境都市工学部（干564-8680 大阪府吹田市山手町3-3-35） \\ E-mail: shimada@kansai-u.ac.jp \\ 4 学生会員 関西大学環境都市工学部都市システム工学科（同上） \\ E-mail: k407446@kansai-u.ac.jp
}

\begin{abstract}
水産資源の維持・増大と漁業経営の安定化に資寸るため, 各地で漁場整備事業が実施されているが，こ うした事業の定量的な効果算定を行うためには，継続的なモニタリング調査等が必要となり，費用面から も定性的な評価にとどまることが多いのが現状である. 本研究では, HEPを灾用して構築した予測モデル をマダイの漁場環境評価に適用しようとして以下の結論を得た。餌料環境のポテンシャルが向上し, マダ イの生息環境は改善したことから, マダイの漁獲量は増加した可能性が示唆された. マダイの全漁獲量の うち約 2 割については, 漁場造成に伴う餌料の増加が寄与寸る可能性が示唆された。本研究により得られ たHEPを応用して構築した予測モデルは, 評価海域の漁獲量の傾向だけでなく, マダイの餌料環境に着目 した漁場環境評価に活用できることが示唆された。
\end{abstract}

Key Words : Intertidal zone, sessile organism, fishing ground environment, Red seabream, HEP

\section{1. 研究の目的}

水産資源の維持・増大を図り漁業経営の安定化に資す るため, 各地で漁場造成をはじめとした自然再生事業が 実施されている。しかしながら，こうした事業の定量的 な効果算定を行うためには，事業着手前の生物環境調査 や事業完了後の継続的なモニタリング調查等が必要とな ることから，費用面からも定性的な評価にとどまること が多いのが現状である.

そこで本研究では, 生物生息環境や漁場環境を簡便か つ定量的に評価ができるハビタット評価手続き1)

(Habitat Evaluation Procedure 以下，「HEP」) を用い,

「潮間帯における付着生物と水質を指標とした漁場環境 評価手法に関する研究2)（以下，「著者らの研究」）」 において構築した予測モデルを, 継続して実施した現地 調査結果等の知見を加えて改良を行った上で，マダイの 漁場環境評価に適用しようとした.

\section{2. 研究の内容}

(1) 調査地点の設定と調査の概要

調査地点の選定は，調査結果を漁場環境の評価に適用 することを前提として既存の水質調査結果の有無, 既存 の付着生物調查結果の有無, 統計資料の有無, 地域の漁 業実態, 現地調査の作業工程等を勘案し, 図-1 に示し た大阪湾, 播磨灘および紀伊水道に面した 6 地点の容易 にアクセスできる人工海浜に設置された石積突堤や人工 磯等の周辺を調查地点として設定した.

調査は，2009年10月から2011年10月にかけて合計10回 実施し, 付着生物の確認種数調査と水質 (水温, 塩分, $\mathrm{pH}, \mathrm{DO}, \mathrm{COD})$ ，および気象（気温・風向・風速等） の観測を行った.

なお，湊（南あわじ市）の調查地点については，第2 回調査より追加し，2009年12月から2011年10月にかけて 合計9回実施した。 


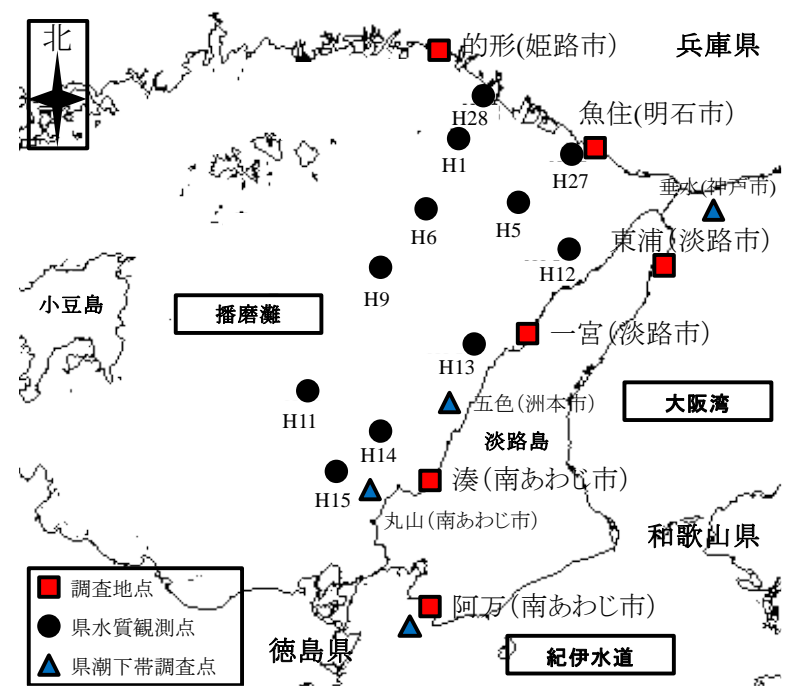

図-1 調査地点位置図

\section{(2) 予測モデルの構築}

\section{a) HEPによよ比較対象と評価対象}

本研究では，現地調查を実施した大阪湾，播磨灘およ び紀伊水道に面する6調査地点をHEPによる比較対象と して設定した.

また，評価の対象は，調查地点で確認された付着生物 とし, 特定の付着生物を対象とするのではなく, 調査地 点で確認された付着生物の種数を評価対象とした。

\section{b) 適正指標(SI)モデルの構築}

HEPによる予測モデルの構築は，現地調査結果やその 他の既存文献を勘案しつつ，基本的に橋中ら ${ }^{3)}$ の方法に 従い，図-2に示したとおり塩分（単位：PSU）, $\mathrm{pH}$, DO (単位 $: \mathrm{mg} / \mathrm{L}$ ), COD（単位 $: \mathrm{mg} / \mathrm{L}$ ) の4項目の適正 指標（Suitability Index 以下，「SI $(x) 」 ）$ モデルの構築を以 下の方法により行った.

まず，付着生物の確認種調査における付着生物の確認 種数と水質の調査結果との関係を散布図にプロットし, 付着生物の確認種数の最大值をnとし，SIの最大值はnを $\mathrm{SI}=1.0$ と設定した。 また, 付着生物の確認種数の最小值 をmとし，SIの最小值はSI=x， $\mathrm{x}=\mathrm{m} / \mathrm{n}$ と設定した．今回の 調査結果については，付着生物の確認種数の最大值 $\mathrm{n}$ 阿万（南あわじ市）におけるn=44であったことからこれ を基準点としてSI=1.0とした．なお，DOが0の環境，す なわち無酸素の環境では生物は生息できないと考えて, $\mathrm{m}=0$ と設定しSIの最小值をSI=0と設定した.

次に，4項目の水質指標に関寸る観測值の範囲内で, それらの点の大部分を包絡するような直線を算出した. また，直線の変化点については，基本的にプロットされ た点を包絡するように変化点を設定し， $\mathrm{SI}_{\mathrm{p}}, \mathrm{SI}_{\mathrm{D}}, \mathrm{SI}_{\mathrm{C}}$ に

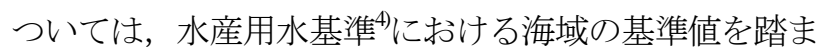
えつつ設定した.
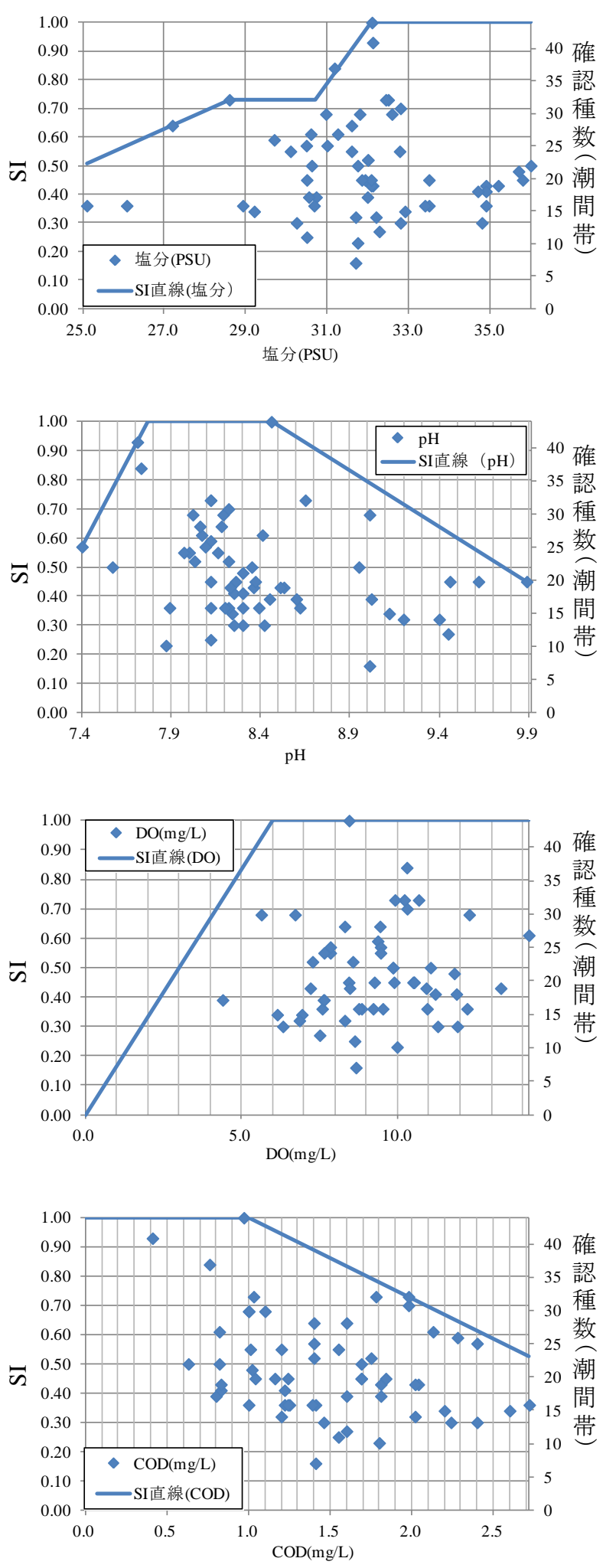

図-2 構築したSIモデル

\section{c) ハビタット適正指標(HSI)モデルの構築}

ハビタット適正指数（Habitat Suitability Index 以下, 「HSI」）モデルの構築についても，橋中ら ${ }^{3)}$ の方法に従 い，SIのう最小のものが付着生物の生息環境に大きく 影響を与え，そこに生息できる種数を制限するとして， 
限定要因法により4項目のSIモデルを統合して式(1)に示 したHSIモデルを構築した。

\section{$\mathrm{HSI}=\min \left(\mathrm{SI}_{\mathrm{S}}, \quad \mathrm{SI}_{\mathrm{p}}, \mathrm{SI}_{\mathrm{D}}, \mathrm{SI}_{\mathrm{C}}\right)$}

\section{d）構築したHSIモデルの検証}

構築したHSIモデルの妥当性を確認するため, 図-3中 には，6調査地点におけるHSI值と付着生物の確認種数最 大值との関係を@印で，HSI と最大值を除く付着生物の 確認種数の関係をム印で示した.

なお，この図には理想的な算出結果を表すものとして， 原点とHSI值および付着生物の確認種数が最大の点 $\{(\mathrm{HSI}, \mathrm{n})=(1,44)\}$ を通る直線を記入した．HSI值の算出結果 の妥当性は, プロットした点がこの直線よりも右下部に あり，かつ，この直線の付近にあることを基準に判断す る.

6調査地点におけるHSI值と付着生物の確認種数最大值 との関係について，図-3中に線形を示したとおり，その 相関係数は $\mathrm{R}^{2}=0.87$ となり概社調查地点周辺の潮間帯に おける付着生物の生息環境を再現したといえる.

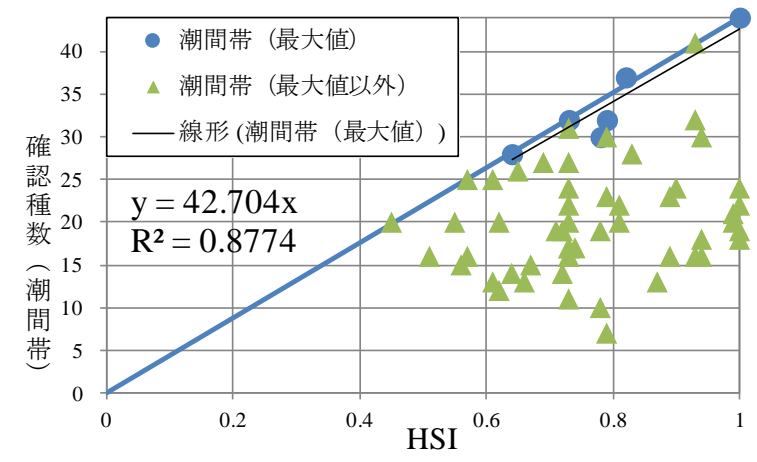

図-3＼cjkstart構築したHSIモデルの検証

\section{（3）潮下帯における付着生物環境への適用}

本研究は，マダイの漁場環境評価を行うことを目的と しているため, 魚介類の餌料環境に重要な潮下帯の付着 生物環境に適用可能力確認を試みた。

まず，図-1に示した定点H13およびH14における1997年 から2006年の10年間の水質観測結果 ${ }^{5}$ （以下，「県水質 観測結果」），同期間における公共用水域調査結果， および瀬戸内海総合水質調査》結果を基にHSI值を算出し た. また, 図-1に示した大阪湾, 播磨灘および紀伊水道 に面する4地点で，兵庫県が実施した潮下帯おいて潜水 士により坪刈した検体の分析結果 ${ }^{8}$ （以下，「県潮下帯 調査結果」)を整理し，それを確認種数（潮下帯）とし て，HSI值との関係について，著者らの研究2)において実 施したのと同様の方法により改めて検討した.

その結果, 図-4に示したとおり, 確認種数 (潮間帯)
と確認種数 (潮下帯) を比較すると, 調查方法, 調査水 深等の調查条件，環境条件等が異なることから，確認種 数 (潮下帯) は, 確認種数 (潮間帯) に比べて高くなる 傾向となってはいるものの, 図-4中に線形を示したとお り, HSI值と確認種数（潮下帯）との相関係数は $\mathrm{R}^{2}=0.88$ となり, 確認種数 (潮下帯) は, 確認種数 (潮間帯) と 同様の傾向を示すことを確認できた.

すなわち，マダイなどの魚介類の餌料環境に重要な潮 下帯における付着生物の確認種数については, 潮間帯と ほぼ同じ傾向を示すことが示唆されており, 調查が容易 に実施できる潮間帯における付着生物の確認種数調査結 果を活用することにより, 調查地点周辺の潮下帯におけ る付着生物の確認種数の傾向が予測できるといえる. ま た, HSI值が高い海域は, 付着生物の種数が豊富な海域 であることから，付着生物を餌料とする魚種にとって餌 料環境のポテンシャルが高い海域であるといえる.

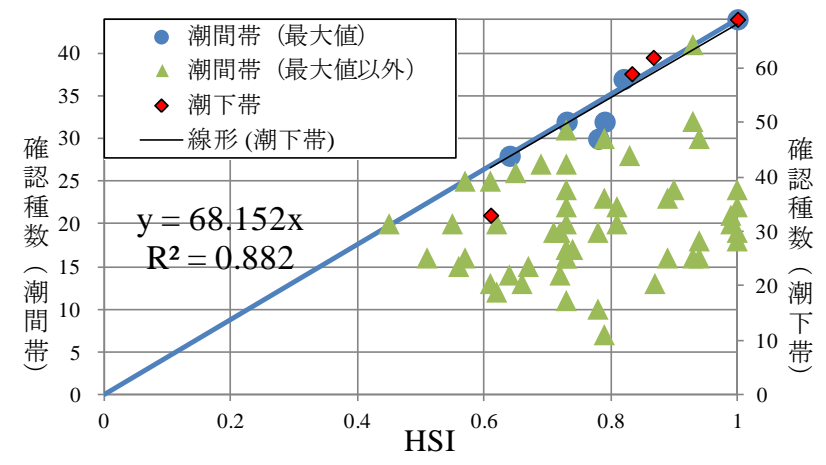

図-4 潮間帯と潮下帯における確認種数の関係

\section{(4) マダイの漁業実態との関係}

著者らの研究旧よる, HSI值の高い海域では魚類の 漁獲量および1経営体当りの漁獲量のいずれも多いこと が示唆されているが，なかでも漁業上有用な魚種である マダイについては，雑食性が強く餌条件の良い場所に高 密度に分布し，回遊性はあるが岩礁や構造物等を餌場と して利用寸る魚種であること，漁場造成における増殖対 象となること等を勘案し, 本研究では，マダイを指標魚 種として選定した.

構築したHSIモデルに，播磨灘の11観測点における 1976年から30年間の県水質観測結果5)適用し，各観測 点におけるHSI值を算出の上，統計資料9 より播磨灘にお ける同期間のマダイの漁獲量の推移を整理し，マダイの 漁獲量とHSI值との関係について考察した。 なお，短期 的な水質変動に伴うHSI值の変動やマダイの漁獲量の変 動の影響を軽減するために，5年平均値により検討した． その結果，図-5に示したとおり，マダイの漁獲量につ いては明らかな増加傾向がみられ，HSI值についても年 変動はみられたものの，1973年に瀬戸内海環境臨時措置 
法（1978年に瀬戸内海環境特別措置法に改正）施行され たことも起因した評価海域の水質改善に伴い1980年代後 半以降上昇する傾向が顕著にみられた。なお，1980年代 前半以前のHSI值が減少傾向となっているのは，1979年 および1984年のCODの観測值が，前後の観測值と比較し ても極端に低い值（1.0 mg/L以下）を示した観測月がみ られたことに起因してHSI值が高い值となったためであ る. それら特異值を除去した場合, 図-5中に点線で示し たとおり全期間においてHSI值は上昇する傾向がみられ ることを確認しているが，本研究では短期的な水質変動 は起こりうるものと考えて，特異值を除去せずに考察を 行うこととした.

また，本研究において構築したHSIモデルは，潮間帯 における付着生物の確認種数を基に構築したことから, マダイの漁獲量にかかる線形と比較すると, 図-6に示し たとおり，直線の傾きは異なるものの，両指標の間に相 関がみられた。

すなわち，HSI值の上昇傾向に伴い，餌料環境のポテ ンシャルが向上し，マダイの生息環境が改善されたこと により, マダイの漁獲量は増加した可能性が示唆された.

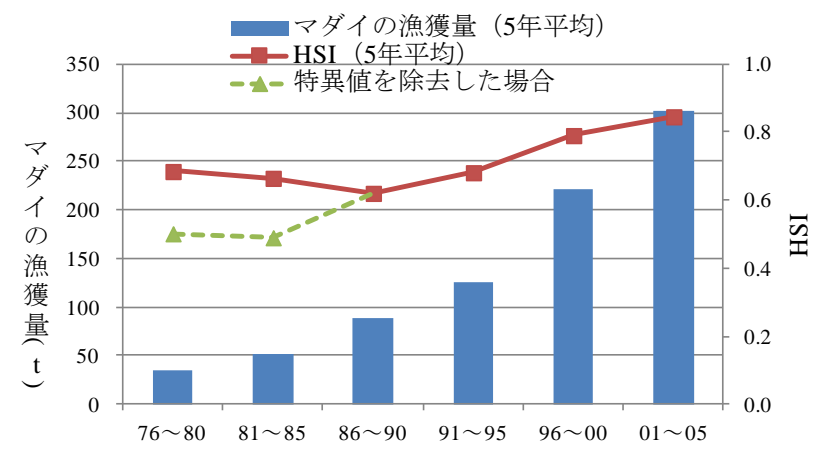

図-5ＨSI值とマダイの漁獲量の推移

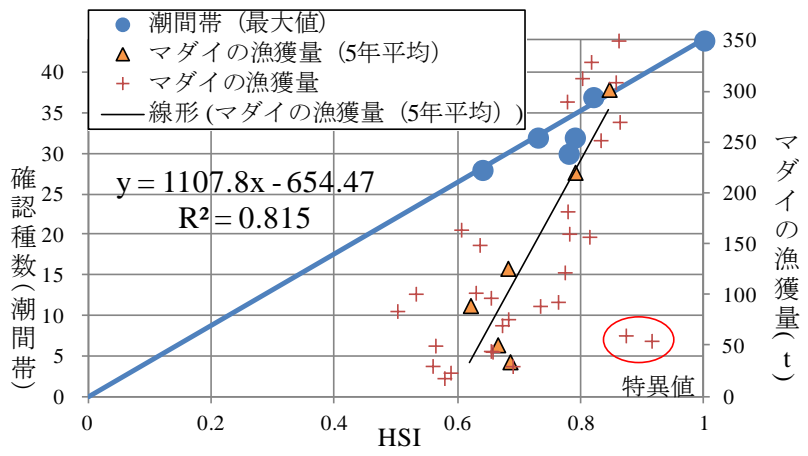

図-6ＨSI值とマダイの漁獲量との関係

\section{(4) 漁場造成との関係}

\section{a) 漁場造成の機能と効果}

漁場造成の機能については, 魚礁等の構造物に魚介類 が集まる蝟集効果や，餌場，産卵場，隠れ場，休憩場等
として利用されることによる魚介類増殖機能があり，魚 介類の成長の促進，幼稚魚等の生残率の向上等の効果が ある10)ことが知られている。

そのうち，本研究では，漁場造成材料として石材や魚 礁等の構造物を投入するとそれらの表面に付着する餌料 生物が増加することに着目し，マダイの漁獲量の推移と 漁場造成の実績との関係について考察することにより， 漁場造成の効果を定量的に評価しようとした.

\section{b) マダイの漁獲量と漁場造成との関係}

マダイの漁獲量と漁場造成との関係を考察するため, 統計資料9)より播磨灘におけるマダイの漁獲量の推移を 整理し, 漁場造成量については, 漁場造成の実績 ${ }^{11)} よ り$ 播磨灘（東播地区，西播地区，淡路西浦地区）における 事業量 $\left(\right.$ 空 $\left.\mathrm{m}^{3}\right)$ を整理したところ，図-7に示したとおり， 漁場造成量の増加に伴い，マダイの漁獲量も増加する傾 向がみられた。

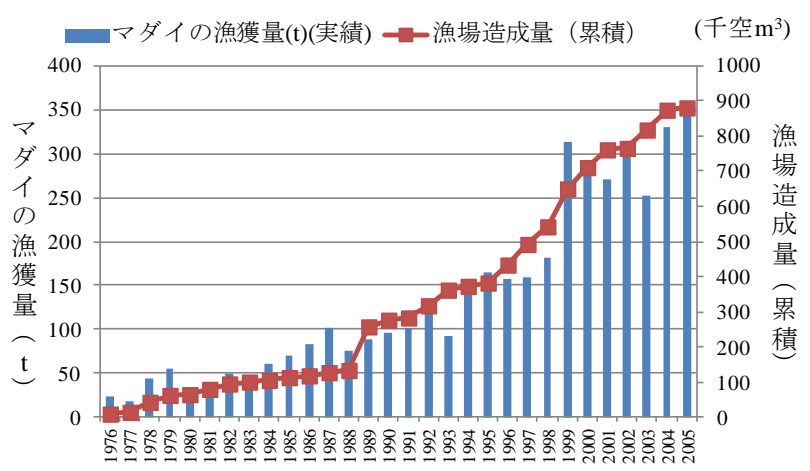

図-7 漁場造成とマダイの漁獲量の推移

\section{c) マダイの漁獲量と種苗放流との関係}

マダイの漁獲量が増加した要因の一つとして，マダイ の漁獲量と瀬戸内海におけるマダイの種苗放流実績(2) と の関係についても考察した。

その結果，HSI值の上昇傾向が顕著にみられる1980年 代後半以降については，図-8に示したように，毎年70万 尾前後のマダイの種苗放流が行われている．また，種苗

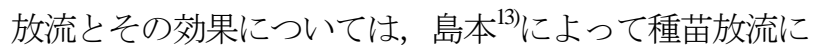

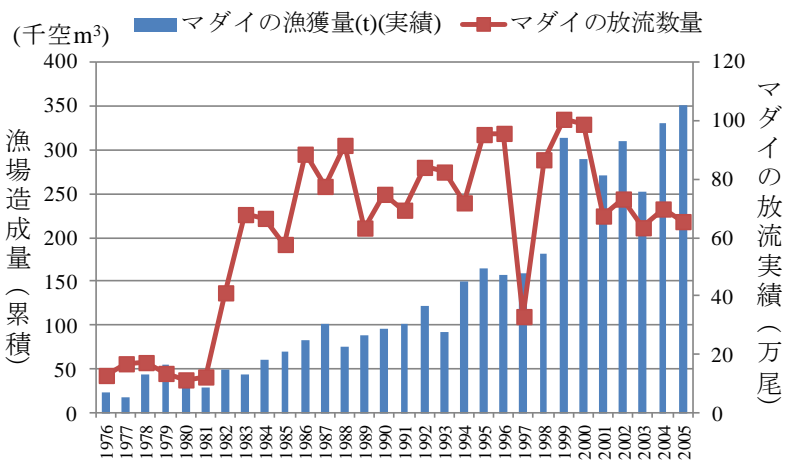

図-8 種苗放流とマダイの漁獲量の推移 
由来する漁獲量が総漁獲量に占める割合は, $1 \%$ 前後で あったことが明らかにされている.

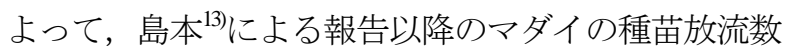
量の変動等の状況について, 別途考慮する必要があるも のの, 漁獲量が増加した原因は, 漁場造成の効果だけで なく, マダイの種苗放流も一因であろう.

\section{d) マダイの増産漁獲量の試算}

マダイの漁獲量が増加した要因について解析寸るため, 基本的に第2の鹿ノ瀬（仮称）構想の推進 ${ }^{14}$ 報告書にお いて実施した試算方法に従って，以下のとおりマダイの 増産漁獲量を試算しようとした。

まず，漁場造成材料として石材や魚礁等の構造物を投 入するとそれらの表面に付着する餌料生物が増加する

「増加餌料現存量」については, 本研究では県潮下帯調 查結果臬を基に考察し，2005年を $2 \mathrm{~kg} / \mathrm{m}^{2}$ とした．過去の増 加餌料現存量については, 評価海域のHSI值の変動を考 慮して, 2005年のHSI值と対象年のHSI值との比率を乗じ て推定した.

また，「増加餌料生物生産量」は，魚類に餌として利 用される年間量として, 以下の算定式(2)により推定し た.

\section{増加餌料生物生産量 $=$ 増加餌料現存量 $\times$ 回転率 $\times$ 利用率}

ここで，前出の報告書 ${ }^{14}$ に基づき，回転率 : 3 , 利用 率: $2 / 3$ とした.

漁場造成 1 空 $m^{3}$ 当りの表面積については, 石材の表面 積や一般的な魚礁の表面積を勘案し, 本研究では, 平均

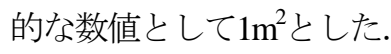

また，選好性餌料 ${ }^{15}$ とは，餌料として好まれ最も価値 が高い餌料動物のことで, 節足動物軟甲類（エビ，カニ 等の類）と環形動物多毛類（ゴカイ等）とされており， 本研究では県潮下帯調查結果 ${ }^{8}$ 考察した結果, 増加餌 料現存量の3\%を「選好性増加䬺料生物量」として試算 した.

推定した選好性増加餌料生物生産量による魚類一増肉 量を基に，マダイの幼稚魚の最大収容尾数に換算し，換 算したマダイの幼稚魚尾数が成長後漁獲されるものとし,

「幼稚魚収容尾数」は，以下の算定式(3)，(4)により算 出した.

幼稚魚収容尾数 $=$ 餌料生物利用量 $\times$ 餌料転換効率 $\div$ 1尾あたりの増加体重量

餌料生物利用量=選好性増加慨料生物生産量 $(\mathrm{g})$ $\times$ 期間率 $\times$ 配分比
ここで，同様に前出の報告書 ${ }^{14}$ に基づき，餌料転換効 率: 0.13 , 期間率 : 3 ケ月/12ケ月, 配分比 : $0.5,1$ 尾あた りの増加体重量 : $0.3(\mathrm{~g})$ とした.

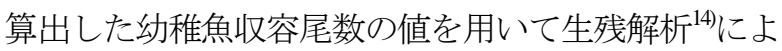
り1976年から30年間の増産漁獲量を算出した。 なお, 本 研究での増産漁獲量の算出は, 漁場造成の 1 年後, 寸な わち，1歳魚から7歳魚までを漁獲対象として積み上げ計 算を行った.

その結果，図-9に示したとおり，マダイの全漁獲量の うち約2割については, 漁場造成に伴う餌料の増加が寄 与寸る可能性が示唆された.

よって, 漁場造成に伴う餌料の増加以外の魚介類増殖 機能，マダイの種苗放流，地域の漁業実態や資源管理の 効果等を別途考慮する必要はあるものの, 魚介類の餌料 となる付着生物の生息環境の改善による餌料環境のポテ ンシャルの向上に加えて, 漁場造成に伴う餌料の増加に 伴い, マダイの生息環境は向上し, マダイの漁獲量は増 加傾向を示したといえる.

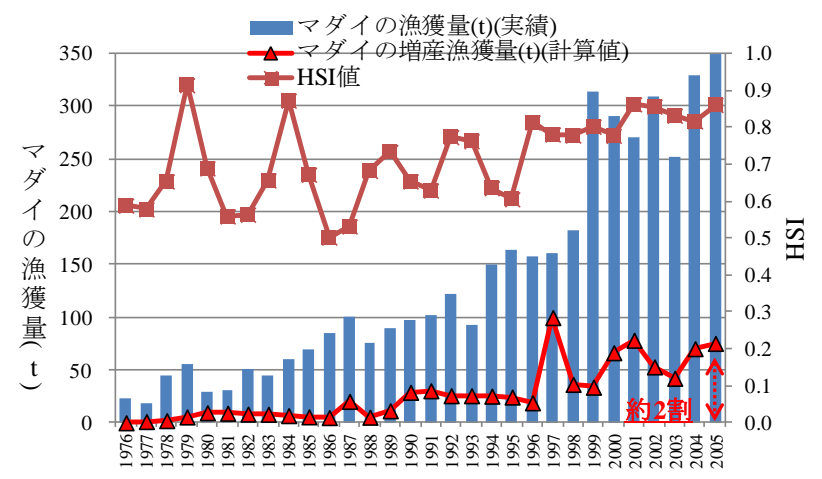

図-9 HSI值とマダイの増産漁獲量との関係

\section{3. 主要な結論}

本研究で得られた主要な結論を以下に示す.

1) 現地調查で得られた付着生物の確認種数調査結果と水 質調査結果より HEP による予測モデルを構築し，付 着生物の生息環境を再現した.

2)調査が容易に実施できる潮間帯における付着生物の確 認種数調査結果を活用寸ることにより, 調查地点周辺 の潮下帯における確認種数の傾向が予測できる.

3)HSI 值が高い海域は，付着生物の種数が豊富な海域で あることから，付着生物を餌料とする魚種にとって慨 料環境のポテンシャルが高い海域である.

4) HSI值の上昇傾向に伴い，餌料環境のポテンシャルが 向上し，マダイの生息環境は改善したことにより，マ ダイの漁獲量は増加した可能性が示唆された. 
5)マダイの全漁獲量のうち約2割については，漁場造成 に伴う餌料の増加が寄与する可能性が示唆され，漁場 造成に伴う餌料の増加に伴い，マダイの生息環境は向 上し, マダイの漁獲量は増加傾向を示した.

以上をまとめると，本研究により得られた HEP を応 用して構築した予測モデルは，評価海域の漁獲量の傾向 だけでなく，マダイの餌料環境に着目した漁場環境評価 に活用できることが示唆された.

\section{4. 今後の課題}

本研究は，HEPの考え方を応用し，付着生物調査結果 を基に構築したHSIモデルをマダイの漁場環境評価に適 用したものであるが，付着生物調査結果より予測モデル を構築するだけでなく，HEPを用いて直接マダイを対象 とする予測モデルを構築した場合についても検討するこ とが望ましいと考える.

また，本研究では別途考慮することとした，漁場造成 に伴う餌料の増加以外の魚介類増殖機能やマダイの種苗 放流等の効果も加えた評価とすることも今後の課題であ 万.

漁場環境を定量的に評価した上で自然再生事業等を実 施することは極めて重要であり，本研究結果が事業効果 の算定等に資するための一助となれば幸いである.

謝辞 : 本研究の遂行にあたり，現地調査に助力してくれ た関西大学環境都市工学部の学生諸君ならびに貴重なデ ータをご提供いただいた関係官庁の各位に感謝の意を表 します。

\section{参考文献}

1) 田中章 : HEP 入門<ハビタット評価手続き>マニュア ル，朝倉書店，2006.

2) 市瀬友啓, 島田広昭, 加藤官司, 高木英男, 中桐 栄：潮間帯における付着生物と水質を指標とした漁 場環境評価手法に関寸る研究, 海洋開発論文集, 第 26 巻, pp.1281-1286, 2010 .

3) 橋中秀典, 井上雅夫, 島田広昭, 田中賢治, 西澤博 志：豊かな付着動物相の形成を目指した人工磯の適 地選定手法, 海岸工学論文集, 第 50 巻, pp.12161220， 2003.

4）社団法人日本水産資源保護協会：水産用水基準 （2005 年版），平成 18 年 3 月.

5) 水質観測結果：（兵庫県立農林水産技術総合センタ 一水産技術センタ一調べ)

6)公共用水域調査 : http://www-gis.nies.go.jp/

7) 瀬戸内海総合水質調査 : http://www.pa.cgr.mlit.go.jp/gicyo/suishitu/

8) 県潮下帯調查結果：(兵庫県調べ)

9）兵庫農林統計協会：兵庫県水産業の動き（平成 9-18 年）。

10）水産庁漁港漁場整備部・財団法人漁港漁場漁村技術 研究所：魚礁における増殖機能の便益計測マニュア ル（平成 19 年 3 月）。

11）漁業造成の実績：（兵庫県調べ）

12) 兵庫県：ひょうごみどり白書 2008 (平成 20 年 12 月）。

13) 島本信夫 : 瀬戸内海東部海域におけるマダイの資源 変動および栽培漁業に関する研究, 兵庫水試研究(35), pp.89-98, 1999.

14）兵庫県・財団法人漁港漁場漁村技術研究所 : 第 2 の 鹿ノ瀬（仮称）構想の推進（平成 22 年 3 月）。

15) 水産庁漁港漁場整備部・財団法人漁港漁場漁村技術 研究所：平成 15 年度水産基盤整備生物調查「原単位 把握のための調査」（魚礁事業における増殖効果指 標検討調査）報告書（平成 16 年 3 月）。

\section{ENVIRONMENTAL EVALUATION MODEL OF RED SEA BREAM WAS CONSTRUCTED BY APPLYING THE HEP}

\section{Tomohiro ICHISE, Sakae NAKAGIRI, Hiroaki SHIMADA, and Masaru KOBAYASHI}

In order to contribute to the stabilization of fishery management and the sustainability of fishery resources, fishery development projecs have been carried out. However, about continuons monitoring surveys, it is not easy to assess these project effects on the relation between fishery and environment because of increasing research cost. In this study, we apply HEP(predictive model) to the environmental assessment in red sea bream fishery, the following conclusions are drawn. Of potential prey environment is improved, catches of red sea bream was increased. For about $20 \%$ of the total catch of red sea bream, improvement is suggested. Therefore, it is suggested that the model can be used for the environmental assessment of red sea bream. 